TAPROBANICA, ISSN 1800-427X. December, 2013. Vol. 05, No. 02: pp. 154-155.

(C) Taprobanica Private Limited, 146, Kendalanda, Homagama, Sri Lanka.

http://www.sljol.info/index.php/tapro

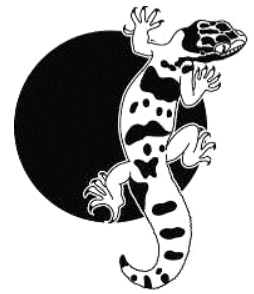

\section{On usage of perches by the Spotted Owlet}

The Spotted Owlet Athene brama (Temminck, 1821), although a common, native species in India (Ali \& Ripley, 1983), is poorly studied (Kumar, 1985; Jadhav \& Parasharya, 2003; Pande et al., 2007). The present study examines the use of various perch substrates and perching heights by Spotted Owlets between 2007 and 2009 in Madurai District $\left(9^{\circ} 30^{\prime} \mathrm{N}, 7^{\circ} 28^{\prime} \mathrm{E}\right)$, Southern India. Four habitats; rural, urban, riverbanks, and agricultural lands (transects of $4500 \mathrm{~m}$ length and $50 \mathrm{~m}$ width were used for each habitat) were selected and surveyed between 18:00 and 22:00 $\mathrm{h}$ for usage of perches. In each survey, perching substrate and perching height used (height on which Spotted Owlet perched) while foraging were recorded following Bell \& Ford (1990). The perching heights were grouped into various class intervals: $0-2 \mathrm{~m},>2-4 \mathrm{~m},>4-6 \mathrm{~m},>6-8 \mathrm{~m},>8-$ $10 \mathrm{~m},>10 \mathrm{~m}$. The chi-square test was applied for testing percent usage of perch substrates and perching heights between habitats.

In total, 1,660 perch data points of Spotted Owlets (411 observations from rural, 435 from urban, 388 from riverbanks, and 426 from agricultural lands) were recorded. The Spotted Owlets used seven different types of perch substrates for hunting prey; of these, utility of electric power lines $(51.3 \%)$ and trees $(28.6 \%)$ were more common than others (buildings $5.4 \%$, shrubs $4.9 \%$, compound walls $3.9 \%$, fence posts $3.7 \%$, and ground $2.2 \%$ ). The height of substrates ranged from 1 to $25 \mathrm{~m}$ : $2-$ $9 \mathrm{~m}$ in rural, $4-25 \mathrm{~m}$ in urban, $1-9 \mathrm{~m}$ in riverbanks, and $1-16 \mathrm{~m}$ in agricultural lands. Although demonstrating considerable range, the majority $(60 \%)$ of Spotted Owlets perched 6-8m above the substrate followed by $4-6 \mathrm{~m}$ (14.9\%), 2-4m (13\%), 0-2m (6.9\%), 8-10m $(4.2 \%)$, and $>10 \mathrm{~m}(1 \%)$.
The usage of perch substrates among habitats was significantly varied $\left(\chi^{2}=135.8 ; \mathrm{df}=6 ; p\right.$ $<0.05)$. The Spotted Owlets perched predominantly on electric power lines in rural $(57.6 \%)$, urban $(51.9 \%)$, and agricultural lands $(60.1 \%)$, while they mostly used trees $(44.2 \%)$ on riverbanks. Other than electric power lines and trees the percent usage of other kinds of perch substrates also varied among habitats. The usage of fence posts $(12.0 \%)$ was common in rural areas; buildings (17.3\%) and compound walls (11.6\%) in urban areas, and shrubs $(16.5 \%)$ in riverbanks.

Usage of perching heights differed significantly among habitats $\left(\chi^{2}=86.8\right.$; $\left.\mathrm{df}=5 ; p<0.05\right)$. In all habitats they usually perched at a height of 6-8m level, but the percent usage ranged from $46.3 \%$ (in riverbanks) to $80.3 \%$ (in agricultural lands). The other dominant perching height preferred by Spotted Owlet was 4-6m (19.2\%) in rural, $8-10 \mathrm{~m}(25.2 \%)$ in urban, $2-4 \mathrm{~m}$ $(32.5 \%)$ in riverbanks and equally $4-6 \mathrm{~m}$ and $8-$ $10 \mathrm{~m}(8.5 \%)$ in agricultural lands.

The Spotted Owlets in our study used manmade perches such as electric power lines (51.3\%) rather than natural perches. The distribution of electric power lines are a common feature in our study area, especially around the human settlements and crop lands. These structures provide ready access and an unobstructed view. On many occasions, Spotted Owlets were found using electric power lines close to street light in use, as light sources attract variety of insects during night hours. Lammers \& Collopy (2007) stated that avian predators are attracted to overhead utility power lines because they provide perches for various activities, including hunting prey. In the absence of electric power lines, Spotted Owlets preferred and utilized other perches such as trees, buildings, shrubs, compound walls and fence posts. However, the preference of perch substrates often varied depending upon habitat 
types and availability and behaviour of prey during foraging.

The Spotted Owlets perched mostly at a height of 6-8m level (60\%), which is highly optimum for efficient foraging of its prey species. High elevated perches may provide a larger field of view (Leyhe \& Ritchison, 2004; Asokan \& Ali, 2010) and increase the chances of detecting prey. Shafir \& Roughgarden (1997) and Butler et al. (2005) stated that distance to prey is a key factor influencing the perching height selection in sit-and-wait predators. However, the nature and height of perches used by Spotted Owlets may be related to the type of prey captured, vegetation structure and availability of perches.

Further work should quantify the availability of perch substrates vs. use of perches by Spotted Owlets.

\section{Acknowledgements}

This study was financed by Ministry of Environment \& Forests, Govt. of India. We are grateful to the Principal and the Management of Saraswathi Narayanan College, Madurai, for facilities and encouragement. We are thankful to P. Muthukumar for assistance with fieldwork. Finally Johanna Bleecker (McGill University, Canada) is acknowledged for language editing.

\section{Literature cited}

Ali, S. and S. D. Ripley, 1983. Handbook of Birds of India and Pakistan. Oxford University Press, Bombay: 236.

Asokan, S. and A. M. S. Ali, 2010. Foraging behavior of selected insectivorous birds in Cauvery Delta region of Nagapattinam District, Tamil Nadu, India. Journal of Threatened Taxa, 2: 690-694.

Bell, H. L. and H. A. Ford, 1990. The influence of food shortage on inter-specific niche overlap and foraging behaviour of three species of Australian warblers (Acanthizidae). Studies on Avian Biology, 13, 381-388.

Butler, S. J., M. J. Whittingham, J. L. Quinn and W. Cresswell, 2005. Quantifying the interaction between food density and habitat structure in determining patch selection. Animal Behaviour, 69: 337-343.
Jadhav, A. and B. M. Parasharya, 2003. Some observations on the nesting behaviour and food of the Spotted Owlet Athene brama. Zoos' Print Journal, 18: 1163-1165.

Kumar, T. S., 1985. The Life History of the Spotted Owlet (Athene brama brama, Temminck) in Andhra Pradesh. Raptor Research Centre, Hyderabad, India: 241.

Lammers, W. and M. W. Collopy, 2007. Effectiveness of avian predator perch deterrents on electric transmission lines. Journal of Wildlife Management, 71: 2752-2758.

Leyhe, J. E. and G. Ritchison, 2004. Perch sites and hunting behaviour of Red-tailed Hawks (Buteo jamaicensis). Journal of Raptor Research, 38: 19-25.

Pande, S., A. Pawashe, M. N. Murlidhar, C. Joglekar and A. Mahabal, 2007. Effect of food and habitat on breeding success in Spotted Owlets (Athene brama) nesting in villages and rural landscapes in India. Journal of Raptor Research, 41: 26-34.

Shafir, S. and J. Roughgarden, 1997. Testing predictions of foraging theory for a sit-and-wait forager, Anolis gingivinus. Behavioral Ecology, 9: 74-84.

Submitted: 22 Nov. 2012, Accepted: 26 August 2013 Sectional Editor: Varadharajan Gokula

A. M. Samsoor $\mathrm{Ali}^{1} \&$ R. Santhanakrishnan ${ }^{2}$

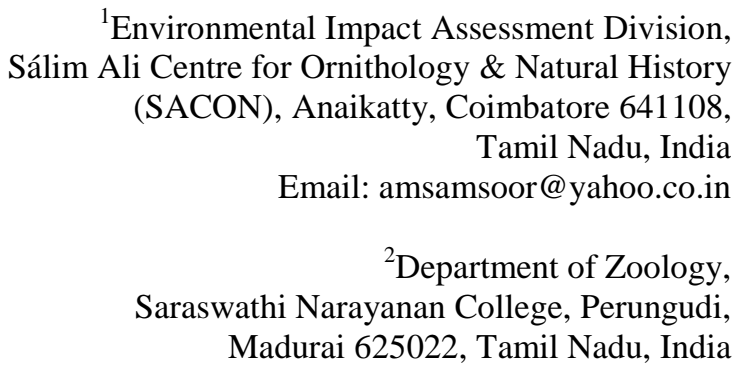

